\title{
O sacerdócio comum dos cristãos na relação entre o laicato e o ministério ordenado
}

\author{
The common priesthood of Christians \\ in the relationship between the laity and the \\ ordained ministry
}

Leomar Antônio Brustolin Rafael Martins Fernandes

\section{Resumo}

O artigo reflete sobre o significado do sacerdócio comum dos cristãos na perspectiva da eclesiologia do Povo de Deus em comunhão, desenvolvida no Concílio Vaticano II. Estuda os fundamentos bíblicos e patrísticos do sacerdócio comum, compreendendo a sua originalidade em relação ao sacerdócio do Antigo Testamento. Trata do sacerdócio de Cristo como fundamento da compreensão do sacerdócio comum dos cristãos. Reflete sobre a eclesiologia total e relaciona a unidade e especificidade da missão sacerdotal, profética e real dos cristãos enquanto povo sacerdotal. Destaca o significado do vocábulo "comum" definido pelo Concílio Vaticano para designar o sacerdócio dos batizados. Distingue a especificidade do exercício sacerdotal do ministério ordenado e a do laicato, enfatizando o sentido da ação dos leigos no mundo. Enfatiza que a identidade eclesial do cristão leigo não pode se estabelecer como o "não clérigo". Embora o sacerdócio comum não seja exclusivo do fiel cristão leigo, a falta de conhecimento da forma como o laicato santifica suas vidas no cotidiano e exerce seu sacerdócio batismal prejudica inclusive o desenvolvimento da ação pastoral e evangelizadora da Igreja. 
Palavras-chave: Sacerdócio comum. Laicato. Eclesiologia. Ministério ordenado. Concílio Vaticano II.

\begin{abstract}
The article examines the meaning of the common priesthood of Christians from the perspective of the ecclesiology of the People of God in communion, developed during the Second Vatican Council. It studies the biblical and patristic foundations of the common priesthood while understanding its originality in relation to the Old Testament priesthood. It looks at the priesthood of Christ as the foundation for understanding the common priesthood of Christians. It digs into total ecclesiology and relates the unity and specificity of the priestly, prophetic and kingly mission of Christians as a priestly people. It highlights the meaning of the word "common" defined by the Vatican Council to designate the priesthood of the baptized. It distinguishes the specificity of the ordained ministry's priestly exercise from that of laity while emphasizing the sense of the action of the lay people in the world. It emphasizes that the ecclesial identity of the lay Christian is not to be established as the "noncleric". Although the common priesthood is not exclusive to the lay Christian faithful, not knowing how the laity sanctify their daily lives and how they exercise their baptismal priesthood also undermines the development of the Church's pastoral and evangelizing action.
\end{abstract}

Keywords: Common priesthood. Laity. Ecclesiology. Ordained ministry. Second Vatican Council.

\title{
Introdução
}

Aprofundar o significado do sacerdócio comum dos cristãos é resgatar um elemento fundamental da eclesiologia proposta na Constituição Dogmática Lumen Gentium do Concílio Vaticano II, mas nem sempre explicitada na prática da realidade eclesial. Há um caminho a ser percorrido para superar a distância entre hierarquia e laicato em muitas comunidades. A proposta conciliar tende a superar o binômio pela relação entre comunidade e ministérios de todos batizados que constituem o único povo sacerdotal $(1 \mathrm{Pd} 2,9)$ com livre acesso a Deus. 
No período pós-conciliar, a doutrina do sacerdócio comum favoreceu a participação mais consciente e ativa do laicato na ação litúrgica e no campo evangelizador. Não faltam, contudo, interpretações que desviam do seu sentido original proposto pelo Concílio. Em determinadas circunstâncias, serviu para difundir um ideal demasiado democratizante de Igreja. Para concretizar os ideais de participação, promoveram-se ministérios leigos sem uma devida preparação teológica e canônica, proporcionando, não raras vezes, confusão de papéis entre pastores e leigos, e a consequente clericalização do laicato. Em outros casos, como reações aos excessos, desenvolveram-se o autoritarismo clerical e determinados tipos de tradicionalismos fundamentalistas que tendem a transformar a doutrina do sacerdócio comum em uma espécie de sacerdócio metafórico, sem incidência real na vida dos cristãos. ${ }^{1}$ Para recuperar a originalidade conciliar, será preciso revisitar os conceitos de sacerdócio, sacrifício e o sentido dos tria munera que o batismo confere. Igualmente, é necessário estabelecer distinções e relações entre o ministério ordenado e a missão dos fiéis cristãos leigos.

\section{A originalidade do sacerdócio de Cristo}

Os Evangelhos não atribuem a Jesus o título de sacerdote. Ele é denominado Mestre, Profeta, Messias, Senhor, entre outros títulos. A ausência, nos Evangelhos, da temática do sacerdócio de Cristo expressa a consciência da Igreja primitiva sobre a necessidade de reelaborar as categorias sacerdotais para poder aplicá-las ao ministério de Cristo. ${ }^{2}$ Quem trata do sacerdócio de Cristo é a Carta aos Hebreus. O autor realizou essa reelaboração ao integrar culto e vida, compreendendo o sacerdócio na vida.

$\mathrm{Na}$ Carta aos Hebreus ( $\mathrm{Hb} 2,17$ ), afirma-se que, para tornar-se sumo sacerdote, Cristo deveria tornar-se, em tudo, semelhante a seus irmãos. A semelhança em tudo não se refere apenas à natureza humana que o Filho de Deus assumiu na encarnação, mas designa, especialmente, os aspectos mais humilhantes da existência humana como as provações, os sofrimentos e a morte.

\footnotetext{
${ }^{1}$ NEUNER, P., Per una teologia del popolo di Dio. Sobre a interpretação do sacerdócio comum em um sentido "metafórico", contraposto ao "verdadeiro" sacerdócio ministerial, ver, sobretudo as controvérsias da reação católica ao protestantismo (séc. XVI-XIX) em: CANOBBIO, G., Laici o cristiani, p. 145-175.

${ }^{2}$ VANHOYE, A., La novità del sacerdozio di Cristo, p. 47-48.
} 
Jesus Cristo, portanto, não foi consagrado sumo sacerdote por meio das cerimônias prescritas no Levítico, mas pelos sofrimentos padecidos na vida e em sua paixão, aceitando-os, com docilidade filial, perfeita e completa solidariedade fraterna. Ele realiza, em si, a transição de uma santificação por meio da separação ritual para uma santificação por meio de um dinamismo de comunhão vivida na existência real. ${ }^{3}$

O Antigo Testamento compreendia a santificação na exterioridade, através de ritos que constituíam um verdadeiro sistema de separação. A primeira separação demarcava a distinção entre o povo de Israel e as outras nações, por intermédio da circuncisão e da observância das leis alimentares. Depois havia o sistema de separação delimitado pelas doze tribos de Israel; assim, a tribo de Levi era separada das demais, e seus membros eram apartados, para se dedicarem ao serviço no templo. Nessa tribo, uma família recebia uma consagração especial para que, do seio dela, saísse um que seria escolhido como sumo sacerdote. Havia também a separação entre o sumo sacerdote e a oferta apresentada a Deus, visto que ele não podia oferecer a si mesmo, pois era pecador; então, deveria oferecer, por si, uma vítima imolada. Enfim, havia a separação entre a vítima e Deus, porque a vítima era um animal e um animal não pode entrar em comunhão com Deus. ${ }^{4}$

Diferentemente de todas essas separações rituais do sacerdócio do Antigo Testamento, o sacerdócio de Cristo é marcado por uma existência que tem um dinamismo de amor extremo. Por seu sangue derramado na cruz, Cristo estabeleceu a abolição de todas as separações antigas e consolidou a plena comunhão entre os cristãos e Deus. Em seu oferecimento na cruz, Ele baniu a separação que existia entre vítima e Deus. Ele não ofereceu um animal para agradar a Deus, mas ofereceu a si mesmo imaculado.

Cristo também aboliu a separação entre sacerdote e vítima, porque o sacerdote antigo não podia oferecer-se a si mesmo, porque não era digno nem capaz de fazê-lo. Cristo, porém, ofereceu a si mesmo, sendo, ao mesmo tempo, sacerdote e vítima. O Crucificado eliminou, enfim, a separação que existia entre povo e sacerdote, porque sua oferta na cruz foi um ato de solidariedade com todos; um ato pelo qual ele tomou sobre si as dores da humanidade, para poder transmitir aos cristãos sua consagração sacerdotal. ${ }^{5}$

\footnotetext{
${ }^{3}$ VANHOYE, A., Il sacerdozio comune dei cristiani, p. 30-31.

${ }^{4}$ VANHOYE, A., La novità del sacerdozio di Cristo, p. 50-51.

${ }^{5}$ VANHOYE, A., Il sacerdozio comune dei cristiani, p. 36-37.
} 
São Paulo, na Carta aos Efésios, atesta que, em Cristo, temos a liberdade de chegar a Deus com plena confiança $($ Ef 3,12), porque, por meio de seu sangue, Cristo eliminou outra separação: aquela entre povo eleito e nações pagãs: "Cristo é nossa paz, aquele que fez de duas coisas uma só, derrubando o muro da separação que dividia, para reconciliar todos os dois com Deus em um só corpo, por meio da cruz" (Ef 2,14-16). ${ }^{6}$

A novidade do sacerdócio de Cristo consiste na sua abertura à participação e não à separação, como no Antigo Testamento. Trata-se de um culto existencial, em completa solidariedade com a condição pecadora da humanidade. ${ }^{7}$ Ele estabelece uma comunidade sacerdotal, de livre acesso a Deus (Hb 10,19-20), ${ }^{8}$ sacramento de Cristo para a humanidade: "linhagem escolhida, sacerdócio régio, nação santa, povo adquirido para apregoar os grandes feitos daquele que vos chamou das trevas à sua luz admirável” (1Pd 2,9).

\section{O sacerdócio dos cristãos}

O Antigo Testamento revela que Israel será um reino de sacerdotes (Ex 19,6; Is 61,6). Esses textos são retomados no Novo Testamento e aplicados à Igreja. Isso ocorre especialmente na Primeira Carta de Pedro e no Apocalipse. Pelo Batismo, o Povo de Deus participa do sacerdócio de Cristo e se constitui como comunidade sacerdotal (1Pd 2,9). O Apocalipse, ao se referir ao Cordeiro imolado, declara: "Resgataste para Deus, com o teu sangue, pessoas de cada tribo, língua, povos e nações, e fizeste deles, para o nosso Deus, um reino de sacerdotes" (Ap 1,6). Esse sacerdócio dos cristãos se caracteriza por oferecer sacrifícios espirituais que têm implicações diretas no ser e no agir dos discípulos de Jesus Cristo.

Pedro explicita que o sacerdócio é exercido quando os cristãos oferecem sacrifícios espirituais agradáveis a Deus:

\footnotetext{
${ }^{6}$ VANHOYE, A., Il sacerdozio comune dei cristiani, p. 37.

${ }^{7}$ Em Cristo, "o sentido sacerdotal da Igreja realiza um deslocamento enérgico dos valores do culto que passam do rito para a vida. E em primeiro lugar, para a vida de Cristo: essa é verdadeiramente o templo, o sacrifício, o sacerdócio, o grande ritual no qual a humanidade encontra Deus" (DIANICH, S., La Chiesa mistero di comunione, p. 42).

${ }^{8}$ Conforme a Carta aos Hebreus, Cristo, Sumo Sacerdote, constituiu seus discípulos como sacerdotes livres para entrarem quando quiserem no Santuário de sua Divindade: "Temos, pois, irmãos, a ousadia de entrar no Santuário, pelo sangue de Jesus: pelo caminho novo e vivo, que ele inaugurou para nós, passando através da cortina, quer dizer, através da sua humanidade" (Hb 10,19-20).
} 
Portanto, despojai-vos de toda maldade, de toda mentira, hipocrisia e inveja, e de toda calúnia. [...] Aproximai-vos do Senhor, pedra viva, rejeitada pelos homens, mas escolhida e valiosa aos olhos de Deus. Do mesmo modo, também vós, como pedras vivas, formai um edifício espiritual, um sacerdócio santo, a fim de oferecerdes sacrifícios espirituais, agradáveis a Deus, por Jesus Cristo (1Pd 2,1-5).

Na primeira parte deste texto, apresentam-se três condições para que a oferta sacerdotal seja possível e válida. A primeira condição é negativa, e as outras duas são positivas. Inicialmente exorta a não ceder a nenhum mal, pois a ruptura com o mal deve ser completa. Em seguida, propõe desejar intensamente o leite espiritual. Provavelmente, o Apóstolo dirigia-se a um grupo de neófitos que haviam recebido recentemente o Batismo e, por isso, os compara a crianças recém-nascidas que desejam o leite materno. ${ }^{9}$ Finalmente, convida a provar quanto o Senhor é bom, pois, ao fazer a experiência do encontro com Ele, o ser humano experimenta a sua bondade. A oferta cotidiana do sacerdócio, portanto, está fundamentada na relação pessoal com Cristo, pois se trata de um reconhecimento amoroso, de uma atitude de permanente ação de graças.

Quando Pedro define os cristãos como "pedras vivas", unidas a Cristo, para formar o edifício espiritual, indica que o sacerdócio deve ser exercido para edificar um templo santo. Todos os cristãos constituem um organismo sacerdotal, um corpo. Nenhum batizado pode exercer esse sacerdócio de forma isolada, pois depende da unidade a qual é chamado a participar na Igreja, corpo de Cristo.

Em seguida, Pedro propõe oferecer sacrifícios agradáveis a Deus. Na linguagem usual, o termo sacrifício indica privação, sofrimento, e a palavra espiritual designa, muitas vezes, algo psíquico ou mental. Pedro, no entanto, emprega o termo sacrificio em sentido religioso. ${ }^{10}$

No Antigo Testamento, os sacrifícios consistiam em imolação de animais. Eram ofícios sagrados realizados por meios materiais. Portanto, ao utilizar o termo espiritual, Pedro esclarece que o sacrifício dos cristãos tem uma natureza diversa daquela compreendida no Antigo Testamento. De

\footnotetext{
${ }^{9}$ VANHOYE, A., Il sacerdozio regale, p. 70.

${ }^{10}$ No Novo Testamento, ocorre uma profunda reelaboração da noção de "sacrifício". Para um aprofundamento deste tema, ver: VANHOYE, A., La novità del sacerdozio di Cristo, p. 53-63; MARX, A.; GRAPPE, C., Sacrifício, p. 1568-1571.
} 
forma similar, Paulo escreve na Carta aos Romanos que os "irmãos, pela misericórdia de Deus, apresentem os seus corpos como sacrifício vivo, santo e agradável a Deus" (Rm 12,1). Ele antepõe esse sacrifício àquele oferecido, no altar do templo, por meio de cadáveres de animais. Os cristãos, portanto, se oferecem a si mesmos como sacrifícios vivos, pois colocam os próprios corpos à disposição de Deus, para o serviço de seu amor no mundo. Entende-se, pois, que a expressão sacrificio espiritual não é compreendida simplesmente como oferta mental, mas como oferta concreta e real de amor e generosidade que se realiza na docilidade do Espírito Santo.

O sacrifício é um ato que santifica uma oferta. Sacrificar e santificar são ações muito similares. Sacrificar significa tornar sagrado, realizando um ofício sacrificial, e santificar significa tornar santo. ${ }^{11}$ Paulo ensina que para ser agradável, a oferta deve ser santificada pelo Espírito Santo. Nos sacrifícios cristãos, o Espírito Santo ocupa o lugar que pertencia ao fogo nos sacrifícios do Antigo Testamento. A grande questão dos cultos antigos era conseguir que uma oferta subisse até Deus, por isso queimavam-se oferendas no altar. Por meio da fumaça que subia, intencionava-se que a oferta fosse elevada até Deus. Dizia-se, então, que Deus aspirava o odor desses sacrifícios que lhe agradavam e, por isso derramava graças sobre a Terra. ${ }^{12}$

Sustentava-se, porém, que nem todo fogo servia para o sacrifício. Era preciso que o fogo descesse de Deus. O Levítico recorda que o culto sacrificial do Povo de Deus foi auxiliado por um fogo vindo de Deus, no momento da inauguração do culto sacerdotal ( $\mathrm{Lv} 9,24)$. Por isso, o fogo deveria estar sempre aceso diante do altar, sem jamais permitir que ele se apagasse (Lv 6,5).

Essa concepção supunha que o ato de sacrificar não é ação humana, mas divina. O ser humano não consegue tornar algo sagrado, pode apenas apresentar sua oferta para que ela se torne sagrada pela ação de Deus. Apesar de válida, essa concepção continha uma imperfeição, pois o fogo divino era material, semelhante a um raio que desce do céu. No Novo Testamento, supera-se essa visão, pois se compreende que o fogo de Deus não é um raio que cai, mas é o próprio Espírito Santo que desce. Para se aproximar de Deus,

${ }^{11}$ SCHNACKENBURG, R., Sacrifício (NT), p. 392-395.

${ }^{12}$ É o que se lê no livro do Gênesis quando Noé, depois de sair da arca, construiu um altar e ofereceu a Deus um sacrifício de animais. Descreve-se que o perfume desse holocausto agradou a Deus e Noé obteve sua benevolência (Gn 8,21). 
o humano não necessita, portanto, de um movimento externo, mas de uma mudança interior, de uma transformação do coração que se realiza pelo e no Espírito Santo. ${ }^{13}$

\section{Todo cristão é sacerdote}

No século II, São Justino de Roma, no Diálogo com Trifão, atesta o caráter coletivo do sacerdócio vivido pelos cristãos, considerados verdadeira descendência dos sumos sacerdotes de Deus, os quais lhe oferecem sacrifícios agradáveis e puros. Ele conclui: “Ora, Deus não aceita sacrifícios de qualquer um, a não ser de seus sacerdotes". ${ }^{14}$

Santo Irineu de Lião apresenta o mesmo sacerdócio numa perspectiva pessoal: "Todos os discípulos do Senhor são sacerdotes, eles que aqui não têm nem campos nem casa em herança, mas servem sempre ao altar e a Deus". ${ }^{15}$

No século IV, Santo Agostinho, comentando o texto de Apocalipse 20,6, declara que todo cristão é sacerdote por ser membro de Cristo, único e verdadeiro sacerdote. Seguindo o ensinamento bíblico, Agostinho especifica o sentido do sacrifício verdadeiro e perfeito:

Por conseguinte, verdadeiro sacrifício é toda obra que praticamos para nos unirmos a Deus em santa união, quer dizer, toda obra relacionada com o supremo bem, princípio único de nossa verdadeira felicidade. Eis porque a misericórdia que alivia o próximo não é, em absoluto, sacrifício, se não feita por amor a Deus. Com efeito, o sacrifício, embora oferecido pelo homem, é coisa divina. ${ }^{16}$

Ao relacionar o sacrifício às obras de misericórdia, o bispo de Hipona delineia o sentido e o objetivo do múnus sacerdotal: "Os verdadeiros sacrifícios são as obras de misericórdia para nós mesmos ou para o próximo que remetemos a Deus. O único objetivo dessas obras é nos livrar da infelicidade

\footnotetext{
${ }^{13}$ Compreende-se, assim, o sentido da expressão sacrifício de suave odor que Paulo emprega para exortar os cristãos: "Caminhai no amor, do mesmo modo como Cristo nos amou e se ofereceu a si mesmo por nós, oferecendo-se a Deus em sacrifício de suave odor" (Ef 5,2; F1 4,18 ). Segundo Vanhoye, o pano de fundo no qual se desenvolve a noção de "sacrifício espiritual" são as dimensões existencial e eucarística; VANHOYE, A., Il sacerdozio regale, p. 80-83.

${ }^{14}$ JUSTINO ROMA, Diálogo com Trifão, 116.

${ }^{15}$ IRINEU DE LIÃO, Adversus Haereses, 8,3.

${ }^{16}$ AgOSTINHO, A cidade de Deus, 10, 6.
} 
e consequentemente assegurar a felicidade". ${ }^{17}$ Agostinho acentua o caráter sacerdotal de todos os habitantes da Cidade de Deus que "se oferece a Deus como sacrifício universal pelo Sumo Sacerdote que, como escravo, chegou até a oferecer-se por nós na sua paixão, para fazer de nós o corpo de uma Cabeça tão grande". ${ }^{18}$ Assim, Agostinho designa sacrifício do mesmo modo que Paulo o caracteriza na Carta aos Romanos, quando convida todo cristão para oferecer-se a si mesmo como "hóstia santa, agradável a Deus" (Rm 12,1). Todo ato de caridade, portanto, exercido no cumprimento do mandamento de amor a Deus e ao próximo é considerado um sacrifício que realiza a comunhão com Deus. Essa união íntima com o Senhor é a finalidade de todo culto cristão, portanto, é a meta do sacerdócio.

Santo Agostinho, ao tratar do sacerdócio dos cristãos supera qualquer tentação de uma espiritualidade individualista que promova práticas de mortificação individual. A originalidade da leitura agostiniana acentua a dimensão de corpo e de eclesialidade que todo cristão, como sacerdote, deve considerar ao realizar seus sacrifícios espirituais. ${ }^{19}$ Sem a comunhão com o único Corpo de Cristo, o sacrifício perde seu sentido, pois todo ato de misericórdia e de culto depende do vínculo com a Cabeça que é Cristo.

A comunhão dos membros do Povo Sacerdotal, em suas diversas expressões, se realiza de forma mais perfeita na Celebração Eucarística: "Este é o sacrifício dos cristãos; muitos sendo um só corpo em Cristo. E esse sacrifício em Cristo a Igreja reproduz incessantemente no sacramento do altar, conhecido dos fiéis, no qual ele é mostrado que, naquilo que ela oferece, ela própria é oferecida". ${ }^{20} \mathrm{Na}$ perspectiva patrística, todo cristão é sacerdote e participa de um povo sacerdotal que é a Igreja de Cristo.

\section{A eclesiologia total do Concílio Vaticano II}

O Concílio Vaticano II acolheu os frutos do movimento bíblico, patrístico e litúrgico do século XX e recuperou a perspectiva comunional da Igreja

\footnotetext{
${ }^{17}$ AGOSTINHO, A cidade de Deus, 10, 6.

${ }^{18}$ AGOSTINHO, A cidade de Deus, 10, 6.

${ }^{19}$ TORRELL, J-P., Um povo sacerdotal, p. 65-66.

${ }^{20}$ AGOSTINHO, A cidade de Deus, 10, 6. Vê-se, nesta osmose entre o sacrifício de Cristo e a oblação dos fiéis, a centralidade que o sacerdócio comum assume na doutrina de Agostinho sobre a Igreja. Para um maior aprofundamento deste tema agostiniano, de valência eucarística, ver: TILLARD, J-M., Carne di Cristo, carne della Chiesa, p. 73-77.
} 
antiga, caracterizada pelo primado da eclesiologia total, determinada pela ideia de que a unidade está antes da distinção. Assim, a variedade ministerial se fundamenta e se sustenta pela riqueza pneumatológica e sacramental do mistério eclesial. ${ }^{21}$ Por isso, a Lumen Gentium colocou o capítulo sobre o Povo de Deus antes dos capítulos sobre a hierarquia e o laicato, respectivamente. Essa estrutura redacional da Constituição dogmática indica que a vida segundo o Espírito, enquanto condição de todo batizado, precede toda articulação e variedade de ministérios. Há, então, uma redescoberta da dimensão carismática de todo o Povo de Deus. O Espírito Santo infunde uma variedade de dons e carismas nos batizados para a utilidade do bem comum. ${ }^{22}$ A eclesiologia total engaja todos os cristãos, porque cada um recebe carismas para o serviço e a comunhão. Ninguém tem o direito de propor a divisão, pois todos os dons e carismas procedem do único Senhor e são concedidos para a edificação do único corpo que é a Igreja (1Cor 12,4-7).

Consequentemente, o binômio hierarquia e laicato, tão presente no modo de pensar e de agir em diversas realidades eclesiais, ficou inadequado após a publicação da Lumen Gentium. Para superar esse binômio, o próprio conceito de laicato precisa ser aprofundado e esclarecido.

\begin{abstract}
A Igreja não se identifica com o ministério hierárquico, em relação ao qual os outros batizados se representariam como totalidade indistinta, como rebanho passivo a ser guiado; não se faz uma Igreja docente em absoluto e uma Igreja absolutamente discente, nem uma Igreja que somente oferece e outra que somente recebe. Na Igreja, todos receberam o Espírito Santo e todos precisam manifestá-Lo na dedicação à vida comum. ${ }^{23}$
\end{abstract}

Por causa dos dons e carismas que o Espírito Santo concede aos batizados, é preciso substituir o binômio hierarquia-laicato pelo binômio comunidadecarismas e ministérios. Os ministérios ordenados e os ministérios dos leigos e leigas, por causa da unidade batismal, eucarística e pneumatológica de todo o Povo de Deus, são evidenciados pela variedade carismática da Igreja. ${ }^{24}$

\footnotetext{
${ }^{21}$ FORTE, B., Sul sacerdozio ministeriale, p. 38.

${ }^{22}$ FORTE, B., Sul sacerdozio ministeriale, p. 39.

${ }^{23}$ FORTE, B., Sul sacerdozio ministeriale, p. 40.

${ }^{24}$ FORTE, B., Sul sacerdozio ministeriale, p. 41.
} 


\section{Sacerdócio Comum na Lumen Gentium}

O Concílio Vaticano II recuperou o significado do sacerdócio régio ou comum dos cristãos, apresentando-o na Lumen Gentium ao lado do sacerdócio ministerial ou hierárquico. A expressão sacerdócio comum nem sempre foi aceita tranquilamente para designar a realidade do sacerdócio de todos os batizados. Os redatores da Lumen Gentium divergiram algumas vezes. A comissão preparatória do texto havia utilizado a expressão sacerdócio universal (universale), para designar que se refere a todos, entretanto alertaram que também poderia indicar que inclui tudo (quod universa complecitur). Outra opção teria sido denominar sacerdócio espiritual para expressar que, por esse sacerdócio, se oferecem vítimas espirituais. No entanto, logo se percebeu que também o sacerdócio ministerial é espiritual, pois foi instituído por um dom do Espírito.

Por questão de estilo e linguagem, escolheu-se o termo comum no sentido de que é um sacerdócio comum (abrangente) a todos os batizados, mesmo que, em algumas línguas, como no português, o vocábulo comum também indique algo de qualidade inferior. Logo, foi preciso discernir que não se concebe que o sacerdócio dado no Batismo, de forma inicial, só estaria completo com o sacerdócio do sacramento da Ordem. Isso facultaria entender que a Ordem aperfeiçoaria o Batismo e indicaria a superioridade cristã do sacerdote ordenado. ${ }^{25}$

$\mathrm{Na}$ Lumen Gentium, as afirmações sobre o sacerdócio comum concentram-se nos parágrafos 10 e 11 e seguem, fundamentalmente, os dados da Sagrada Escritura. Trata-se de um "sacerdócio santo" que, inicialmente, não é denominado "sacerdócio comum", expressão que aparece somente na segunda parte do parágrafo 10. Embora os dois termos designem a mesma realidade - os batizados - aqui se acentua mais a vida da graça, destacando "toda atividade do homem cristão", especialmente a oração, os sacrifícios espirituais, a oferta da vida e do testemunho profético. ${ }^{26}$

\footnotetext{
${ }^{25}$ A discussão terminológica sobre o sacerdócio dos cristãos, desencadeada no Vaticano II, foi descrita com propriedade pelo perito conciliar Gerard Philips, ver: PHILIPS, G., L'Église et son mystère au $\mathrm{II}^{\circ}$ Concile du Vatican, p. 146-149.

26 "Na verdade, os batizados, pela regeneração e pela unção do Espírito Santo, são consagrados para serem casa espiritual, sacerdócio santo, para que, por meio de todas as obras próprias do cristão, ofereçam oblações espirituais e anunciem os louvores daquele que das trevas os chamou à sua admirável luz (1Pd 2,4-10). Por isso, todos os discípulos de Cristo, perseverando na oração e louvando a Deus (At, 2,42-47), ofereçam-se a si mesmos como hóstias vivas, santas, agradáveis a Deus (Rm 12,1), deem testemunho de Cristo em toda parte e àqueles que lhe pedirem deem razão da esperança da vida eterna que neles habita (1Pd 3,15)" (LG 10).
} 
O sacerdócio comum dos batizados comporta dois aspectos interligados: primeiro, os habilita a participar ativamente do culto cristão; segundo, lhes atribui o sacerdócio da vida santa, pela qual oferecem sacrifícios espirituais. Ambos os aspectos estão unidos, mas podem acidentalmente estar separados. Por exemplo, alguém pode perder o estado de graça, sem perder o caráter do Batismo. Por outro lado, a vida na graça pode existir sem o sacramento do Batismo manifestamente recebido; é o caso dos justos não batizados, como explicita a Lumen Gentium. ${ }^{27}$ Nesse caso, não existe o sacerdócio comum, pois falta o caráter batismal a esses justos, mas não se pode negar a oferta de vida santa que é marcada pela graça real, sacerdotal e profética, sem ser sacramental. ${ }^{28}$

O parágrafo 11 da Lumen Gentium explicita essa dinâmica interna do sacerdócio comum, dada na interação entre a participação no culto e a vida santa. Ensina que, pelo Batismo os cristãos são destinados ao culto cristão e, regenerados como filhos de Deus, devem confessar, diante da humanidade, a fé que de Deus receberam por meio da Igreja. Pelo sacramento da Confirmação, eles são mais perfeitamente vinculados à Igreja, enriquecidos com uma força especial do Espírito Santo e obrigados a difundir a fé por palavras e obras, como verdadeiras testemunhas de Cristo. Pela Eucaristia, oferecem a Deus a vítima divina e a si mesmos com ela. Dessa forma, quer pela oblação, quer pela sagrada comunhão, não indiscriminadamente, mas cada um a seu modo, todos tomam parte na ação litúrgica. Pelo sacramento da Penitência, os batizados obtêm a misericórdia de Deus e se reconciliam com a Igreja, que haviam ferido com seu pecado. Pela Unção dos Enfermos, toda a Igreja encomenda os doentes ao Senhor padecente e glorificado, para que os salve. Associando-os livremente à paixão e morte de Cristo, favorecem todo o Povo de Deus. Aqueles que são assinalados com a Ordem ficam encarregados de apascentar os cristãos com a palavra e a graça de Deus. Os cônjuges cristãos, pelo sacramento do Matrimônio, participam do mistério da unidade do amor fecundo entre Cristo e a Igreja e têm, assim, em seu estado de vida e em sua ordem, um dom próprio no Povo de Deus. Por esses meios de salvação, todos os batizados, seja qual for sua condição ou estado, são chamados pelo Senhor à perfeição do Pai, cada um por seu caminho. ${ }^{29}$

O Concílio Vaticano II também deixou claro que não é evangélico pensar que os clérigos - ministros ordenados - sejam mais importantes e mais dignos, sejam "mais" Igreja do que os leigos. Esta mentalidade, errônea em

${ }^{27}$ LG 16.

${ }^{28}$ TORRELL, J-P., Um povo sacerdotal, p. 142-143.

${ }^{29}$ LG 11. 
seu princípio, esquece que a dignidade não advém dos serviços ministeriais que cada um exerce, mas da própria iniciativa divina, sempre gratuita, da incorporação a Cristo pelo Batismo. ${ }^{30}$ É necessário estabelecer, portanto, a relação e a distinção entre sacerdócio comum e ministério ordenado.

\section{A relação entre o sacerdócio comum e o sacerdócio ministerial}

Em meio ao povo sacerdotal, Deus chama alguns membros e lhes confia o ministério da participação no sacerdócio de Cristo formalmente como Cabeça, Pastor e Esposo da Igreja. Trata-se do sacerdócio ministerial do qual se participa mediante a Ordem sacramental. Comum a todos são os dons da Aliança e do Espírito Santo, o sacerdócio universal e a participação de todos no múnus profético de Cristo. Nesse sentido, o sacerdócio ordenado é compreendido como uma especificação ministerial daquilo que é comum a todos.

Ambos os sacerdócios procedem do único sacerdócio de Cristo, sendo sua diferença essencial (essentia) e não somente em grau (gradu). ${ }^{31}$ Segundo a Lumen Gentium, o sacerdócio ministerial e o comum ordenam-se um em relação ao outro, porém de formas distintas que se traduzem na capacidade de serviço do primeiro para com o segundo. O Concílio Vaticano II destaca que ambos os sacerdócios possuem distinção essencial. Portanto, se distinguem mais profundamente do que a diferenciação existente entre os graus do diaconato, do presbiterado e do episcopado. ${ }^{32}$

O sacerdócio ministerial tem a missão de formar e guiar (efformat et regit) o povo sacerdotal e foi estabelecido para realizar o sacrifício eucarístico

\footnotetext{
${ }^{30}$ CNBB, Doc. $105,109$.

31 "Sacerdotium autem commune fidelium et sacerdotium ministeriale seu hierarchicum, licet essentia et non gradu tantum different" (LG 10).

${ }^{32}$ Sobre a expressão "essentia [...] different", os teólogos apresentam diferentes modos de interpretação. Peter Neuner mostra-se contra uma interpretação tomada a partir da filosofia escolástica, que induziria à compreensão da existência de uma diferença ontológica entre os sacerdócios e, consequentemente, levaria a uma qualificação superior do sacerdote ordenado em relação ao leigo. Segundo o autor, este modo de ver as coisas é demasiado mecanicista e não estaria de acordo com a mensagem evangélica. O dominicano Jean-Pierre Torrell, por sua vez, não desqualifica a palavra "essência", como se esta ocupasse um plano secundário no parágrafo 10 da Lumen Gentium. Ele explica que, com este termo, os Padres conciliares quiseram expressar as diferentes naturezas desses sacerdócios, assemelhando-se apenas por analogia. Os dois sacerdócios são diversos e derivam do único sacerdócio de Cristo. Neste caso, se há uma superioridade, esta se encontra no sacerdócio real dos batizados, porque confere a participação no Reinado de Deus; NEUNER, P., Per una teologia del popolo di Dio, p. 217-219; TORRELL, J-P., Um povo sacerdotal, p. 144-146.
} 
em nome da pessoa de Cristo e para oferecê-lo em nome de todo o Povo de Deus. O sacerdócio ordenado habilita seu ministro a agir como mediador, sendo representante tanto de Cristo (in nomine Christi) quanto de todo o povo cristão (in nomine ecclesiae). ${ }^{33}$

O Decreto Presbyterorum Ordinis ensina que "o ministério do presbítero existe em favor da Igreja; é para a promoção do exercício do sacerdócio comum de todo o Povo de Deus". ${ }^{34}$

Seguindo a eclesiologia do Povo de Deus em comunhão - ou de totalidade - explicitada na Lumen Gentium, Presbyterorum Ordinis apresenta o sacerdote ordenado relacionando-se com os demais batizados como um:

\begin{abstract}
Irmão entre os irmãos: Embora os sacerdotes do Novo Testamento, em virtude do sacramento da Ordem, exerçam no Povo e para o Povo de Deus o múnus de pais e mestres, contudo, juntamente com os fiéis, são discípulos do Senhor, feitos participantes do seu reino pela graça de Deus que nos chama, regenerados com todos na fonte do Batismo, os presbíteros são irmãos entre os irmãos, membros dum só e mesmo corpo de Cristo cuja edificação a todos pertence. ${ }^{35}$
\end{abstract}

De outra parte, o sacerdócio comum está voltado ao sacerdócio ministerial (ad invicem ordinantur), pois sem a pregação da Palavra, a graça dos sacramentos e a direção pastoral dos ministros ordenados, os membros do sacerdócio comum estariam privados da assistência que Cristo quer lhes oferecer por meio do Espírito Santo. A Exortação Apostólica pós-sinodal Pastores dabo Vobis, de 1992, assinala que:

Quanto mais se desenvolve o apostolado dos leigos, tanto mais fortemente é sentida a necessidade de ter sacerdotes que sejam bem formados, sacerdotes santos. Assim, a própria vida do Povo de Deus manifesta o ensinamento do Concílio Vaticano II sobre a relação entre o sacerdócio

\footnotetext{
${ }^{33}$ LG 10. A expressão in persona (in nomine) Christi também ocorre em outros textos conciliares: LG 21, 25, 27, 28; PO 2; SC 33. A noção in nomine ecclesiae (ou in nomine plebis) completa o sentido desta primeira expressão e aparece também em: PO 2 e 5; SC 33, 83-85. Deve-se, contudo, afirmar que não se pode fazer um uso restrito dessas fórmulas para os ministros ordenados. Isto, porque o cristão leigo também pode agir em nome de Cristo para conferir os sacramentos do Batismo e do Matrimônio, quando as circunstâncias exigirem e permitirem; TORRELL, J-P., Um povo sacerdotal, p. 148-158.

${ }^{34}$ PO 9.

${ }^{35}$ PO 10.
} 
comum e o sacerdócio ministerial ou hierárquico. Pois, no mistério da Igreja, a hierarquia tem um carácter ministerial. Quanto mais se aprofunda o sentido da vocação própria dos leigos, tanto mais se evidencia o que é próprio do sacerdócio. ${ }^{36}$

O sacerdócio ministerial não significa, em si, um grau maior de santidade relativamente ao sacerdócio comum dos fiéis. Trata-se de um dom particular outorgado pelo sacramento da Ordem, para que os ministros possam ajudar o Povo de Deus a exercitar, com fidelidade e plenitude, o sacerdócio comum que lhes é conferido pelo Batismo. ${ }^{37}$

Entre os dois sacerdócios há semelhanças e distinções. Aprincipal semelhança consiste em que ambos derivam do sacerdócio exclusivo de Cristo, oferecem sacrifícios e são consagrados para oferenda da Eucaristia. A diferença está no fato de que o sacerdócio comum é uma realidade da vida na graça, e o sacerdócio ministerial é um carisma a serviço da vida na graça. Ambos oferecem sacrifícios, mas o sacerdócio comum oferece sacrifícios espirituais, e o sacerdócio ministerial oferece sacrifícios rituais, ainda que o sacrifício da Eucaristia seja um sacrifício espiritual por excelência. As oferendas por eles apresentadas se distinguem: no sacerdócio comum, o fiel oferece em seu próprio nome o sacrifício e, assim, colabora para a oferenda de todos; no sacerdócio ministerial, há uma oferenda em nome da assembleia. O fiel somente representa a si mesmo na celebração de culto, ele age como um membro entre outros no corpo. No sacerdócio ministerial, o ministro, além de representar a si mesmo como batizado, assume o papel de Cristo Cabeça em relação aos outros membros do corpo. ${ }^{38}$

Tanto o sacerdócio comum como o ministerial derivam do sacerdócio de Cristo Cabeça, em dois sentidos do termo: cabeça - princípio vital (sacerdócio comum) e cabeça - princípio de autoridade, fonte do ministério (sacerdócio ministerial). Conclui-se que não há relação de subordinação do sacerdócio comum ao sacerdócio ministerial. Ambos dependem definitivamente de Cristo, fonte de toda graça e de todo ministério.

A Evangelii Gaudium explicita a relação entre ambos os sacerdócios:

O sacerdócio ministerial é um dos meios que Jesus utiliza ao serviço do seu povo, mas a grande dignidade vem do Batismo, que é acessível a

\footnotetext{
${ }^{36}$ PDV 3.

${ }^{37}$ PDV 17.

${ }^{38}$ TORRELL, J-P., Um povo sacerdotal, p. 146-147.
} 
todos. A configuração do sacerdote com Cristo Cabeça - isto é, como fonte principal da graça - não comporta uma exaltação que o coloque por cima dos demais. Na Igreja, as funções não dão justificação à superioridade de uns sobre os outros. ${ }^{39}$

\section{A missão específica dos leigos no sacerdócio comum}

O Concílio Vaticano II, destacando a presença da Igreja no mundo, dedicou especial atenção aos fiéis leigos, orientando-os a "cumprir fielmente os seus deveres terrenos, guiados pelo espírito do Evangelho". ${ }^{40}$ Especificamente sobre o laicato, Bruno Forte destaca que o leigo é um batizado, um homo christianus, ungido por Cristo, no Espírito Santo, por meio dos sacramentos. O teólogo italiano adverte, porém, que também o bispo, o presbítero e o diácono são, antes de tudo, batizados e, por isso, cristãos. "Por isso, de uma parte se pode dizer de forma geral 'cristãos', mais do que leigos e não leigos, clérigos e não clérigos, de outra parte, é preciso haver uma definição a partir do ministério: a variedade na unidade e o específico na totalidade". ${ }^{40}$ Nesse sentido, os cristãos batizados recebem do Espírito Santo os carismas e ministérios.

O ministério ordenado representa e apresenta Cristo enquanto Cabeça do seu corpo, que é a Igreja. Agindo "in persona" de Cristo Cabeça, o ministro ordenado está a serviço da unidade do Povo de Deus por meio do anúncio da Palavra (dimensão profética), da celebração dos sacramentos (dimensão sacerdotal) e do cuidado pastoral (dimensão real). ${ }^{41}$

Os leigos participam do sacerdócio de Cristo por meio de sua vida e ação no mundo, convivendo com as realidades terrestres e fermentando o cotidiano com o Evangelho, tornando-se "sal da terra e luz do mundo". Assim, Cristo concede-lhes a graça de tomar parte "de seu múnus sacerdotal no exercício do culto espiritual, para que Deus seja glorificado e os homens salvos". ${ }^{42}$

O decreto conciliar Apostolicam Actuositatem destacou a tríplice participação dos leigos no múnus sacerdotal, profético e real de Cristo, o qual implica uma ação evangelizadora para impregnar e aperfeiçoar a realidade com o espírito do Evangelho. O laicato dá claro testemunho de Cristo e contribui para a salvação da humanidade. Recorda-se que é próprio do estado

\footnotetext{
${ }^{39}$ EG 104.

${ }^{40}$ FORTE, B., Sul sacerdozio ministeriale, p. 42.

${ }^{41}$ FORTE, B., Sul sacerdozio ministeriale, p. 43.

${ }^{42}$ LG 34.
} 
dos leigos viver no meio do mundo e das ocupações seculares, por isso, eles são chamados por Deus para, cheios de fervor cristão, exercerem, como fermento, seu apostolado no meio do mundo. ${ }^{43}$

A participação na missão profética, indica que os leigos têm a missão de anunciar o Evangelho em todos os âmbitos da vida humana "para que brilhe a força do Evangelho na vida cotidiana, familiar e social". ${ }^{44}$ Essa tarefa implica anúncio e denúncia, afinal é preciso também combater o poder das trevas que insiste em dominar o mundo em suas multiformes manifestações.

Pela participação na função régia, configurados a Cristo, os leigos apresentam-se tanto com o termo rei, quanto com o termo pastor, servindo a Cristo na pessoa do próximo, especialmente daquele faminto, sedento, preso, doente, despido, estrangeiro, etc. Cristo se vale de seus servidores para expandir o Reino da verdade e da vida, da santidade e da graça, da justiça, do amor e da paz (Rm 8,12 ). Essa concepção faz com que os cristãos descubram, progressivamente, o lugar central que Cristo ocupa na história e no cosmos. Consequentemente, toda ocupação e toda atividade do leigo, na sociedade, tendem a se tornar um serviço ao humanismo integral e solidário, sinal do Reino que virá.

Quanto à participação na missão sacerdotal, especificamente sobre o sacerdócio dos leigos, ensina o Decreto Apostolicam Actuositatem:

O dever e o direito ao apostolado advêm aos leigos da sua mesma união com Cristo Cabeça. Com efeito, inseridos pelo Batismo no Corpo místico de Cristo, e robustecidos pela Confirmação com a força do Espírito Santo, é pelo Senhor mesmo que são destinados ao apostolado. São consagrados em ordem a um sacerdócio real e um povo santo (1Pd 2,4-10) para que todas as suas atividades sejam oblações espirituais e por toda a terra deem testemunho de Cristo. ${ }^{45}$

Sobre a cooperação entre leigos e presbíteros, Apostolicam Actuositatem sublinha que, por participarem do múnus sacerdotal, profético e real de Cristo, os leigos têm parte ativa na vida da Igreja. "A sua ação dentro das comunidades eclesiais é tão necessária que, sem ela, o próprio apostolado dos pastores não pode conseguir, na maior parte das vezes, todo o seu efeito". ${ }^{46}$

\footnotetext{
${ }^{43}$ AA 2.

${ }^{44}$ LG 35.

${ }^{45}$ AA 3.

${ }^{46}$ AA 10.
} 
A Exortação Apostólica pós-sinodal Christifideles laici, destaca que o laicato é vocacionado por Cristo para realizar uma tarefa original, insubstituível e não delegável. ${ }^{47}$ Especificamente sobre o sacerdócio comum dos fiéis, no que tange aos leigos, a Exortação considera que "a missão salvífica da Igreja no mundo realiza-se, não só pelos ministros, que o são em virtude do sacramento da Ordem, mas também por todos os fiéis leigos: esses, com efeito, por força da sua condição batismal e da sua vocação específica, na medida própria e cada um, participam no múnus sacerdotal, profético e real de Cristo". ${ }^{48}$

\section{Conclusão}

É preciso considerar que a maioria dos membros do Povo de Deus é constituída por leigos. Os ministros ordenados, em minoria, estão intimamente relacionados a esta maioria, a quem servem para que vivam na graça. Embora tenha aumentado, após o Concílio Vaticano II, a consciência da identidade e missão dos cristãos leigos, ainda restam desafios que expressam a não recepção da doutrina do sacerdócio comum, como explicitada na Lumen Gentium.

Uma tarefa que permanece para a Teologia e a pastoral, como desdobramento desta reflexão sobre o sacerdócio comum, refere-se ao aprofundamento da identidade eclesial do cristão leigo que não pode se estabelecer como o "não clérigo". Vivendo sua condição cristã no âmbito do mundo e oferecendo sacrifícios com ofertas do cotidiano, vivido entre luzes e sombras, o leigo pode compreender melhor sua missão singular. O sacerdócio comum não é exclusivo do fiel cristão leigo, mas a falta de conhecimento da forma como o laicato santifica suas vidas e exerce seu sacerdócio batismal prejudica inclusive o desenvolvimento da ação pastoral e evangelizadora da Igreja. Trata-se de uma redução eclesiológica muito séria.

O Papa Francisco com insistência tem reagido contra o mal do clericalismo que se desvia de uma adequada compreensão da eclesiologia total do Povo de Deus. Ele afirma que o clericalismo é a atitude que anula a personalidade dos cristãos e tende a diminuir e a subestimar a graça batismal que o Espírito Santo confere a cada cristão. Isso ocorre, porque em alguns casos, os leigos "não se formaram para assumir responsabilidades importantes, noutros por não encontrar espaço nas suas Igrejas particulares para poderem exprimir-se

\footnotetext{
${ }^{47}$ CfL 28.

${ }^{48}$ CfL 23.
} 
e agir, por causa dum excessivo clericalismo que os mantém a margem das decisões". 49

Para o bem da comunidade eclesial, o sacerdócio ordenado precisa ser exercido por meio do discernimento e da coordenação dos dons e serviços de todos os fiéis cristãos. Os ministros ordenados são chamados a reconhecer, valorizar e harmonizar na totalidade o carisma de cada um. ${ }^{50}$ Por isso, é indispensável que aquele que coordena a comunidade tenha facilidade em dialogar, escutar e aproximar-se de cada batizado para destacar o papel que cada um pode exercer para o bem comum. Isso implica na capacidade de escutar mais do que ser escutado, caminhar junto, evitando decisões arbitrárias e, especialmente, considerando a complexa cultura e sociedade do século XXI, com suas feridas e fragmentos, onde a autoridade não é reconhecida sem diálogo, espírito de comunhão e engajamento total de todos. O sacerdócio comum dos fiéis supõe um maior protagonismo do laicato e uma melhor compreensão do sacerdócio ordenado como dom para fazer toda a Igreja, Corpo de Cristo.

\section{Referências bibliográficas}

AGOSTINHO. A cidade de Deus: contra os pagãos. Petrópolis: Vozes, 2013. v.1.

CANOBBIO, G. Laici o cristiani. Elementi storico-sistematici per uma descrizione del cristiano laico. Brescia: Morcelliana, 1992.

CNBB. Cristãos leigos e leigas na Igreja e na sociedade: sal da terra e luz do mundo (Mt 5,13-14). São Paulo: Paulinas, 2016. (Doc. 105).

CONCÍLIO VATICANO II. Constituição Dogmática Lumen Gentium sobre a Igreja. In: COSTA, L. (Org.). Documentos do Concílio Ecumênico Vaticano II. (1962-1965). São Paulo: Paulus, 1997. p. 101-197.

CONCÍLIO VATICANO II. Constituição Sacrossanctum Concilium sobre a Sagrada Liturgia. In: COSTA, L. (Org.). Documentos do Concílio Ecumênico Vaticano II. (1962-1965). São Paulo: Paulus, 1997. p. 33-86.

CONCÍLIO VATICANO II. Constituição Pastoral Gaudium et Spes sobre a Igreja no mundo de hoje. In: COSTA, L. (Org.). Documentos do Concílio

\footnotetext{
${ }^{49}$ EG 102.

${ }^{50} \mathrm{AA} 3$.
} 
Ecumênico Vaticano II. (1962-1965). São Paulo: Paulus, 1997. p. 539-661. CONCÍLIO VATICANO II. Decreto Apostolicam Actuositatem sobre o apostolado dos leigos. In: COSTA, L. (Org.). Documentos do Concílio Ecumênico Vaticano II. (1962-1965). São Paulo: Paulus, 1997. p. 369-409. CONCÍLIO VATICANO II. Decreto Presbiterorum Ordinis sobre o ministério e a vida dos presbíteros. In: COSTA, L. (Org.). Documentos do Concílio Ecumênico Vaticano II. (1962-1965). São Paulo: Paulus, 1997. p. 491-538. DIANICH, S. La Chiesa mistero di comunione. Genova: Marietti, 1987. FORTE, B. Sul sacerdozio ministeriale. Milano: Paoline, 1989.

FRANCISCO, PP. Exortação Apostólica Evangelii Gaudium. Sobre o anúncio do Evangelho no mundo atual. São Paulo: Paulinas, 2013.

IRINEU DE LIÃO. Adversus Haereses. São Paulo: Paulus, 1995.

JOÃO PAULO II, PP. Exortação Apostólica Pós-Sinodal Christifideles Laici - sobre $a$ vocação e missão dos leigos na Igreja e no mundo. São Paulo: Paulinas, 1990.

JOÃO PAULO II, PP. Exortação Apostólica Pós-Sinodal Pastoris dabo Vobis - sobre a formação dos sacerdotes. São Paulo: Paulinas, 1992.

JUSTINO DE ROMA. Diálogo com Trifão. São Paulo: Paulus, 1995.

MARX, A; GRAPPE, C. Sacrifício. In: LACOSTE, J-Y. (Eds.). Dicionário Crítico de Teologia. São Paulo: Loyola, 2004. p. 1568-1571.

NEUNER, P. Per una teologia del popolo di Dio. Brescia: Queriniana, 2016. PHILIPS, G. L'Église et son mystère au II $^{\circ}$ Concile du Vatican. Histoire, texte et commentaire de la Constitution Lumen gentium. Paris: Desclée, 1967. v. I.

SCHNACKENBURG, R. Sacrifício (NT). In: BAUER, J. B. (Eds.). Dicionário bíblico-teológico. São Paulo: Loyola, 2004. p. 392-395.

TILlARD, J-M. Carne di Cristo, carne della Chiesa. Alle sorgenti dell'ecclesiologia di comunione. Magnano [Itália]: Qiqajon, 2006.

TORRELL, J-P. Um povo sacerdotal. São Paulo: Loyola, 2014.

VANHOYE, A. La novità del sacerdozio di Cristo. In: VANHOYE, A.; MANZI, F.; VANNI, U. Il sacerdozio della nuova alleanza. Milão: Ancora, 1999. p. 45-64. 
VANHOYE, A. Il sacerdozio regale. In: VANHOYE, A.; MANZI, F.; VANNI, U. Il sacerdozio della nuova alleanza. Milão: Ancora, 1999. p. 65-83.

VANHOYE, A. Il sacerdozio comune dei cristiani secondo san Pietro e nella Lettera agli Ebrei. Roma: AdP, 2011.

Leomar Antônio Brustolin

Doutor em Teologia pela Universidade São Tomás de Aquino (Roma)

Docente de Teologia na Pontifícia Universidade Católica do Rio Grande do Sul Porto Alegre /RS - Brasil E-mail: Leomar.brustolin@pucrs.br

Rafael Martins Fernandes Doutor em Teologia pela Universidade Lateranense (Roma) Docente colaborador pelo PNPD/Capes no PPG em Teologia da Pontifícia Universidade Católica do Rio Grande do Sul Porto Alegre / RS - Brasil E-mail: padrerafaelfernandes@gmail.com

Recebido em: 20/04/20 Aprovado em: 17/06/20 